\title{
¿CÓMO FORTALECER EL PODER LEGISLATIVO FEDERAL EN MÉXICO?: EL CASO DE LA REELECCIÓN INMEDIATA DE LOS MIEMBROS DEL CONGRESO
}

\author{
¿HOW TO STRENGTHEN THE FEDERAL LEGISLATURE \\ IN MEXICO: THE CASE OF THE IMMEDIATE RE-ELECTION \\ OF MEMBERS OF CONGRESSMAN
}

\section{David Alberto JAIMES DELGADO*}

RESUMEN: Hoy en día el tema de la reelección legislativa inmediata es una de las asignaturas pendientes y largamente postergadas en la agenda del Poder Legislativo federal mexicano, dicha reforma que forma parte de la también largamente esperada reforma del Estado es de vital importancia si de verdad queremos contar con legisladores profesionales, expertos y responsables ante los ciudadanos. Así pues, el presente trabajo se estructura en seis pequeños apartados en los cuales se hace un breve recuento histórico de las principales causas que motivaron esta, sin duda grave, anomalía constitucional, así como las consecuencias que la implementación de la misma ha traído al interior del Poder Legislativo en México y al Estado en su conjunto.

Palabras clave: Poder Legislativo, diputado, senador, no reelección consecutiva, reelección legislativa inmediata, democracia.
ABSTRACT: Today the issue of immediate legislative reelection is one of the unresolved and largely neglected in the agenda of the Mexican federal legislature, the said reform is a part of the long-awaited reform of the state is of vital importance if we really want we have professionals, experts and accountable legislators to the citizens. This paper is divided into six small sections in which a brief historical account of the major causes that triggered this undoubtedly serious constitutional anomaly, and the consequences that the implementation of it has brought within the legislative branch in Mexico and the State as a whole.

* Doctorando por el Instituto de Derecho Parlamentario de la Facultad de Derecho de la Universidad Complutense de Madrid. 


\section{INTRODUCCIÓN}

El avance democrático en México ha dado pasos agigantados en los últimos años, la organización autónoma de los procesos electorales y la imparcialidad del Tribunal Electoral del Poder Judicial de la Federación han institucionalizado las bases para la competencia plena y equitativa entre los partidos políticos.

Asimismo, la alternancia en todos los niveles de gobierno transcurre en forma legal y pacífica, hecho que a su vez dibuja una pluralidad política más definida y la necesidad de establecer nuevos mecanismos que faciliten la cooperación bajo el nuevo signo de los gobiernos divididos.

Por tal motivo el Poder Legislativo necesita recobrar su vitalidad así como sus facultades de verdadero órgano fiscalizador del Poder Ejecutivo. Sin embargo, es también un hecho que hoy perduran algunas instituciones de las que se sirvieron los gobiernos priístas para desvirtuar la división de poderes y allegarse de una mayoría disciplinada y subordinada cuyos intereses radicaban más en la obtención de escaños en el Congreso y puestos en la administración pública que en la representación de los intereses del pueblo. Es en contra de estos resabios por los que se busca reincorporar al orden constitucional mexicano la reelección legislativa inmediata de los diputados federales y senadores como un paso fundamental para avanzar hacia la consolidación de la democracia representativa. Es decir la democracia mexicana no será eficaz sin devolver el control a los ciudadanos sobre sus representantes. Si es así, entonces aquí cabe preguntar ¿por qué en más de 70 años no se ha restablecido la reelección inmediata al interior del Poder Legislativo federal?, y de implementarse esta propuesta ¿habría consecuencias?, ¿cuáles serían éstas?, ¿serían positivas o negativas?, ¿cómo impactarían en la sociedad y en el sistema de partidos? Por las anteriores consideraciones es que me he permitido redactar este escrito el cual se estructura en seis pequeños apartados en los cuales se establecen algunos conceptos, se describen y analizan los eventos históricos que originaron esta sin duda grave anomalía constitucional y se estudian los principales argumentos tanto a favor como en contra de la propuesta que presento ya que, hoy en día no existe argumento de peso que sostenga una tesis contraria a la propuesta que planteo, así como tampoco existen argumentos históricos que prevengan de dar este importante paso. Por el contrario, la reelección inmediata de los legisladores estuvo presente a lo largo de la historia de nuestra tradición jurídica salvo en los casos de la Constitución de Cádiz de 
1812 y la Constitución de Apatzingán de 1814. A partir del nacimiento de la vida independiente de México, la Constitución Federal de 1824, las Constituciones centralistas de 1836 y 1843, la Constitución de 1857 y la Constitución de 1917 en su texto original, la reelección inmediata de los miembros del Poder Legislativo ha estado presente como reflejo de la voluntad del pueblo mexicano.

La histórica frase de Francisco I. Madero "Sufragio efectivo no reelección" se enarboló para combatir un sistema corrompido por la perpetuación del general Porfirio Díaz en el poder, pero en ningún momento se contempló en sus objetivos políticos que se abarcara a los integrantes del Congreso de la Unión, ideario que así fue recogido y plasmado en la Constitución de 1917, en donde se estableció como principio inamovible la no reelección para el titular del Poder Ejecutivo.

Fue hasta la reforma publicada en el Diario Oficial de la Federación, el 29 de abril de 1933, cuando se prohibió la reelección inmediata legislativa, esto a iniciativa del Partido Nacional Revolucionario (antecedente del PRI) que en una Convención Extraordinaria celebrada en la ciudad de Aguascalientes los días 30 y 31 de octubre de 1932 tomó tan histórica y grave decisión. Dicha Convención fue la respuesta del partido al planteamiento formulado por Plutarco Elías Calles en su informe del 1o. de septiembre de 1928, en el que aseguró el paso al régimen de instituciones y anticipó la idea de la no reelección presidencial absoluta.

A partir de la ponencia sobre el principio de la no reelección que fue presentada por el Comité Ejecutivo Nacional, presidido por el general Manuel Pérez Treviño, dicho principio quedó contenido en diez conclusiones, sin embargo en el tema que nos ocupa me limitaré a señalar que en la quinta conclusión se estableció:

5a. Los senadores o diputados al Congreso de la Unión no podrán ser reelectos para el periodo inmediato. Los senadores y diputados suplentes podrán ser electos para el periodo inmediato con el carácter de propietarios, siempre que no hubieren estado en ejercicio; pero los senadores y diputados propietarios no podrán ser reelectos para el periodo inmediato con el carácter de suplentes.

La ponencia proponía en términos generales la aplicación del principio de no reelección en todos los niveles de gobierno, y como vemos en esta 5a. conclusión se plantea la no reelección inmediata para diputados y senadores y a partir de entonces este principio quedó consagrado en nuestro artículo 59 constitucional. 
Una vez analizadas las conclusiones, tenemos que al dictaminarse la ponencia, el segundo día de la Convención, se dio un interesante debate del que surgieron otras propuestas, de las cuales algunas fueron aceptadas e incorporadas y otras fueron desechadas, entre las propuestas que fueron aceptadas tenemos las siguientes:

Una adición que contempló, por una parte, la aceptación de la reelección para los senadores y diputados suplentes que no hubiesen estado en funciones y por otra, la prohibición de que los propietarios fuesen reelectos como suplentes en el periodo inmediato, ambas incorporadas en el segundo párrafo del artículo 59 de nuestra actual Constitución.

La formulada por Francisco Terminel "por la que se amplió la limitación de reelección de los diputados a las Legislaturas estatales y se dispuso que los propietarios no fueran suplentes en el periodo inmediato". ${ }^{1}$ Actualmente contenida en el segundo párrafo de la fracción II del artículo 116 constitucional.

Tenemos pues que el dictamen con las propuestas incorporadas fue aprobado el mismo 31 de octubre de 1932.

En la Cámara de Senadores se recibió y dio lectura al oficio adjunto al que se remitió el proyecto, durante la sesión ordinaria efectuada el 20 de diciembre de 1932, turnándose a las Comisiones Unidas de Puntos Constitucionales y Gobernación.

En la sesión ordinaria efectuada el 26 del mismo mes y año, se dio lectura al proyecto y al dictamen emitido por las Comisiones antes mencionadas y se aprobó por unanimidad

Una vez agotado el procedimiento previsto en el artículo 135, respecto a la aprobación por las Legislaturas de los Estados, se efectuó el cómputo correspondiente y se declaró aprobada, durante la sesión extraordinaria del Congreso general celebrada el 20 de marzo de 1933.

En el Diario Oficial de la Federación del 29 de abril de 1933 se publicó la reforma aprobada.

Tenemos entonces, que la no reelección consecutiva fue producto de una campaña política dirigida a fortalecer y consolidar la coalición política organizada en el PNR, esta fue patrocinada por los máximos líderes del PNR como estrategia para resolver el conflicto de ambiciones entre los políticos encumbrados y los políticos aspirantes, conflicto que amenazaba

1 Diario de los Debates de la Cámara de Diputados, del 16 de noviembre de 1932, p. 10 . 
con potenciar la fuerza de la oposición y frustrar el proyecto de la dirigencia del partido de construir una organización que aglutinara a todos los grupos políticos como fuera posible. La no reelección consecutiva buscó ampliar la competencia a puestos de elección y permitir al PNR asimilar líderes políticos emergentes mediante la rotación obligatoria de cargos en todos los niveles de gobierno. La rápida rotación de cargos sirvió para apagar el conflicto de ambiciones que conduce a la formación de oposición electoral en los partidos políticos, de esta manera se dio un poderoso incentivo para el desarrollo de los nuevos cuadros políticos.

Así pues, como podemos observar de lo anteriormente expuesto uno de los efectos más importantes de la no reelección consecutiva, fue la incorporación de nuevos cuadros al Partido Nacional Revolucionario. Con ello se incrementó la capacidad del partido para cooptar movimientos sociales y organizaciones políticas emergentes "la rotación forzosa de cargos permitió a la dirigencia nacional del PNR contar con la capacidad suficiente para incorporar movimientos y asociaciones que se gestaban independientemente del partido". ${ }^{2}$

La no reelección legislativa inmediata permitió que el partido se convirtiera en una organización monopólica en lo referente a la provisión de oportunidades legislativas y políticas, tanto a nivel federal como local.

Con este movimiento periódico de cuadros se lograba evitar la radicalización de los perdedores inmediatos, esta prohibición logró reducir la polarización de intereses y posicionamientos que se producían al interior del partido cuando no se lograba el éxito individual o grupal en la obtención de las candidaturas. En la búsqueda de la candidatura, el perdedor en la primera oportunidad, sabía que esa oportunidad perdida en una primera contienda, se actualizaría en la segunda, puesto que el cargo quedaba vacante ante la imposibilidad de permanecer en él por más de un periodo. La seguridad de que existía la posibilidad de volver a competir y de nuevas vacantes hacía que los políticos procedieran racionalmente; ya que optaban por permanecer en la organización en vez de desertar, pues existía la certidumbre de que el cargo volvería a quedar libre dentro de un periodo de espera que era relativamente corto ( 3 años) en el caso de los diputados

2 Nacif, Benito, La no reelección consecutiva y la persistencia del partido hegemónico en la Cámara de Diputados de México, Documento de trabajo de la división de estudios políticos, núm. 63, CIDE, 1997, p. 3. 
y en el caso de los senadores (6 años) esta situación era otro aliciente para no abandonar la organización partidista.

Por otro lado, la no reelección legislativa inmediata trajo como beneficio adicional, en el marco de la circulación de liderazgos, el hecho de que la dirigencia nacional del partido podría, gracias a esta norma, controlar a los indisciplinados o desleales. Por ejemplo, un diputado o senador que no había sido leal al partido era totalmente reemplazable por otro que cubriera mejor las expectativas, el político desleal no iba a ser nuevamente nominado para una candidatura por el partido y por lo tanto no volvería a ocupar otro escaño. El beneficio consistía en que la circulación de cuadros daba al partido el poder de excluir a los desleales, indisciplinados o enemigos.

Podemos señalar entonces que la rotación de cargos terminó transformando al partido político que la convirtió en práctica constitucional en una organización cohesiva y centralizada, en consecuencia la no reelección consecutiva trajo consigo un profundo e irreversible cambio en el equilibrio de poderes del gobierno federal.

La no reelección consecutiva redefinió los objetivos de los miembros del Congreso, transformó a esta institución en un trampolín hacia otras oportunidades políticas en los gobiernos federales y estatales. La rotación forzosa de cargos destruyó el vínculo que ataba las ambiciones de los políticos a sus distritos y a sus puestos en el Congreso, esta conexidad se sustituyó por los contactos en el partido y en la administración pública como estrategia para el avance de sus carreras políticas. La conducta estratégica predominante que nació de este marco anti reeleccionista produjo que los legisladores del PRI, durante el régimen autoritario, para avanzar en sus carreras políticas tuvieran que vincularse y subordinarse al principal nominador: el presidente de la República, en su papel de jefe real del partido, el presidente se convirtió en el punto focal de los esfuerzos de diputados y senadores preocupados por avanzar en sus carreras. Por ello, se volvieron responsables ante el titular del Poder Ejecutivo y no ante sus electores; este fenómeno invirtió la dirección de la responsabilidad política, desde abajo (electores) hacia arriba (presidente).

Tenemos entonces que el principio de no reelección en el Legislativo esta mas bien restringido que prohibido, al limitarse éste, a no poder darse en periodos sucesivos, por ello, se estimó necesario prolongar los periodos de ejercicio correspondientes a fin de que en el desempeño de sus fines, funciones y cometidos, dos años para los diputados y cuatro para los senadores, resultaban escasos para ello, ya que no se podrían 
duplicar o triplicar dichos términos. Se pensó entonces en una duración intermedia y se llegó así a los tres y seis años para la duración del tiempo de encargo de diputados y senadores el cual se mantiene en la actualidad

Así pues, desde 1933, el ciudadano tiene amputado el poder de controlar, supervisar y calificar la actuación de sus representantes, esta situación no puede continuar así ya que desde entonces se ha perdido una oportunidad histórica para profesionalizar el Poder Legislativo de la Unión, lo que a su vez ha debilitado aún más la función legislativa y ha contribuido a perder el prestigio del Congreso.

Desde entonces, los esfuerzos por reabrir nuevamente el debate y la posibilidad de restablecer la reelección de los miembros del Congreso de la Unión ha estado ausente, o no ha tenido el eco suficiente en la agenda legislativa del partido que gobernó más de 70 años la vida política de México, debido a la eficiencia con que esta institución le garantizó al presidente de la República la disciplina de los legisladores de su propio partido.

Tuvo que ser un diputado de oposición en 1964 quien señalara por primera vez las deficiencias en que estaba incurriendo nuestro sistema político al impedir la reelección inmediata de los legisladores y en consecuencia presentara una iniciativa que volviera al espíritu jurídico que caracterizó a México antes de la reforma de 1933. Vicente Lombardo Toledano como diputado del Partido Popular Socialista argumentó correctamente que al carecerse del sistema de reelección inmediata los legisladores "no podrían adquirir los conocimientos, ni las experiencias que el cargo de representante del pueblo y de la Nación exigen".

Respecto a esta iniciativa que presentó Lombardo Toledano cabe señalar que fue dictaminada por las Comisiones Unidas, Primera de Puntos Constitucionales y Segunda de Gobernación de la Cámara de Diputados y fue aprobada en el Pleno. Sin embargo, en la Cámara de Senadores las Comisiones Unidas, Primera de Gobernación y Segunda de Puntos Constitucionales presentaron un dictamen en donde se proponía no aprobar la iniciativa de la colegisladora, por lo que el proyecto fue desechado. A pesar de que la iniciativa no prospero, su valor radicó en haber sido un precedente y abrir un fecundo debate en donde se señalaron correctamente varias ventajas de la reelección legislativa que hasta el día de hoy continúan ratificándose por distintos investigadores de la comunidad académica las cuales señalaremos y detallaremos en el desarrollo del presente trabajo. Así como también las posibles desventajas que la misma acarrearía y los posibles efectos que la misma produciría. 
Así pues, podemos considerar que hoy el sufragio efectivo ha reabierto nuevamente las puertas para que la reelección legislativa inmediata de diputados federales y senadores, pueda ser aprobada a la brevedad posible y así dar un paso firme en la consolidación democrática y en el fortalecimiento del Poder Legislativo, ya que nuestros legisladores no pueden ser eternos amateurs que cada tres y seis años aprenden y ensayan con el destino de nuestro país, no podemos seguir teniendo legisladores inexpertos, ineficaces, tan mal informados y comprometidos sólo con sus partidos". México necesita legisladores que produzcan legislación de calidad, que le den continuidad a sus proyectos, que tomen medidas cuando las leyes implementadas por ellos mismos no sean adecuadas o necesiten arreglos, en síntesis México necesita legisladores profesionales, de carrera que les permita ser verdaderos expertos de la materia parlamentaria". ${ }^{3}$

Asimismo deben desterrarse de una vez por todas y para siempre viejos mitos y miedos en el sentido de que la reelección legislativa inmediata no debe verse como un privilegio del diputado federal o senador, sino por el contrario debe verse como un atributo del ciudadano para premiar la labor efectiva de su representante, o bien, para sancionar el pésimo desempeño de quien simula llevar al Congreso de la Unión los intereses de su pueblo. No debemos olvidar que la reelección no sólo sirve para darle continuidad al buen trabajo y al buen desempeño del diputado o senador que se lo ha ganado, sino que la reelección sirve también para deshacerse de los malos legisladores, de aquellos que sólo atienden sus propios intereses y conveniencias y se olvidan de su verdadera función, de trabajar en favor del pueblo quien fue finalmente quien los puso ahí, debemos tener muy en cuenta que un legislador que no es refrendado por su electorado difícilmente podrá ser elegido para otro cargo de elección popular y así, por ejemplo, se haría una especie de selección natural que paulatinamente iría eliminando a los malos congresistas y a los malos políticos. Además hay que tener muy en cuenta que si la población tiene a salvo la prerrogativa de sancionar a sus diputados y a sus senadores desaparecerá la irresponsabilidad parlamentaria, los espectáculos grotescos o las frivolidades que por ahora no tienen castigo popular.

Lujambio, Alonso, "La reelección de los legisladores: las ventajas y los dilemas", México, Quórum, enero de 1996, p. 23. 


\section{LA REELECCIÓN Y LA NO REELECCIÓN DEL EJECUTIVO}

Respecto al concepto de reelección tenemos diversas acepciones y puntos de vista, unos en el sentido de aceptarla y otros no, así tenemos el criterio del doctor Dieter Nohlen ${ }^{4}$ quien es uno de los politólogos más connotados del mundo y quien sostiene que "la reelección es el derecho de un ciudadano (y no de un partido) que ha sido elegido y ha ejercido una función pública con renovación periódica de postular y de ser elegido una segunda vez o indefinidamente para el mismo cargo (ejecutivo) o mandato (parlamentario)"5 Este mismo autor establece un vínculo muy fuerte entre el principio de no reelección y la tradición histórica particular de América Latina, ya que en el conjunto de países latinoamericanos ha existido una tendencia muy notoria de los ejecutivos a perpetuarse en el poder y de prácticas antidemocráticas muy establecidas como el fraude electoral y la corrupción política en general. Estos dos fenómenos: presidencialismo y corrupción, han legitimado el principio de no reelección como símbolo político e instrumento imprescindible del constitucionalismo democrático. Esto es importante porque a partir de ello podemos entender que la experiencia latinoamericana en la que se encuentra México, al padecer de experiencias reeleccionistas, dictatoriales y fraudulentas, provocaron que la no reelección se instituyera como norma democrática constitucional indispensable.

La no reelección se entiende también como la exigencia de alternar en el poder, y si bien la no es una condición de los regímenes democráticos, adquiere plena legitimidad en este contexto, como instrumento indispensable para impedir el continuismo en el gobierno. Lo anterior aplica por supuesto en el caso de México donde el principio de alternabilidad se materializa en el principio de no reelección, es decir, en México la legitimidad misma del orden político, dada nuestra experiencia histórica con diversos presidentes, es percibida como dependiente del hecho de la alternancia en el poder, al

4 También pueden consultarse el Diccionario universal de términos parlamentarios, léxico y discurso parlamentario, México, LVI Legislatura, Cámara de Diputados-Porrúa, 1997, t. I; Santo, Víctor de, Diccionario de ciencias jurídicas, políticas, sociales y de economía, 2a. ed., Argentina, Universidad, 1999; Cabanellas de Torres, Guillermo, Diccionario jurídico elemental, Argentina, Heliastra, 1988.

5 Nohlen, Dieter et al., Tratado de derecho electoral comparado en América Latina, México, Fondo de Cultura Económica-Instituto Interamericano de Derechos Humanos, 1998. 
grado de consagrarse constitucionalmente y de tener una vigencia de más de 70 años sin sufrir alteración.

Uno de los constitucionalistas mexicanos más destacados como el doctor Felipe Tena Ramírez señaló que este principio de no reelección es en sí mismo antidemocrático ${ }^{6}$ ya que:

Donde las funciones cívicas se ejercitan con libertad y son respetadas, no hay razón alguna para que el pueblo este impedido de reelegir al funcionario, al contrario, si éste ha demostrado su aptitud en el ejercicio del poder debe hallarse en mejores condiciones que el candidato que por no haber ocupado el puesto no ha aprendido todavía la prueba definitiva de su aptitud y que además, carece de experiencia en el cargo. ${ }^{7}$

Debemos tener en cuenta que la no reelección del Ejecutivo por su parte, puede ser considerada una decisión jurídica y política fundamental que el constitucionalismo mexicano ha venido delineando y puntualizando a través del tiempo. Con este fin cabe señalar en primer término, que el estudio de nuestra historia pone de manifiesto que la permanencia prolongada de los hombres en el poder constituyó el problema político de mayor envergadura durante el primer siglo de nuestra vida independiente; de ahí que las dos grandes revoluciones de nuestra existencia nacional autónoma, la Revolución liberal de Ayutla y la Revolución Social de 1910, se iniciaron en abierta lucha contra la inmovilidad gubernamental que engendró gobiernos dictatoriales al margen de la ley.

Entonces, uno de los pilares de nuestro sistema político descansa sobre la no reelección del presidente de la República, y es que a lo largo de más de siete décadas nos ha dado estabilidad política, por lo cual es un principio que no debemos siquiera tratar de modificar en lo que al presidente de la República se refiere.

6 Véase en el mismo sentido a Arnaut, Alberto, "La no reelección consecutiva de legisladores" México, Crónica Legislativa, 2001; Fernández Ruiz, Jorge, Poder Legislativo, México, Porrúa, 2003; Carpizo, MacGregor, Jorge, Estudios jurídicos en torno a la Constitución de 1917, México, UNAM, 1998.

7 Tena Ramírez, Felipe, Derecho constitucional mexicano, 37a. ed., México, Porrúa, 2005 , pp. 222 y 223. 


\section{LA REELECCIÓN LEGISLATIVA}

En estos últimos años hemos sido protagonistas de un proceso de transición, esto es, un periodo en el cual está cambiando el régimen político de México; en este proceso de tránsito hacia la democracia, se están consolidando las instituciones.

Las condiciones se están presentando para que se incremente el profesionalismo y el poder político del Congreso; por ello, ahora es urgente tener una idea clara de que el desempeño de nuestros legisladores mejoraría si pudiesen reelegirse inmediatamente, a fin de que se especialicen en la creación de mejores leyes, lo cual optimizaría el que hacer legislativo que con lleve a una mejor formación de legisladores, ya que de lo que se trata es de contar con un Poder Legislativo fuerte, vigorizado y con operación eficiente, que cumpla con sus funciones de análisis, deliberación y discusión en torno a los grandes problemas que afectan a la población y que proponga soluciones a los mismos; que regule las facultades y abusos del Ejecutivo, que vigile y controle su actuación y que permita, en la medida que aglutine las fuerzas políticas más representativas, avanzar en la democracia.

Jeffrey Weldon ${ }^{8}$ señala cuatro condiciones que explican a su juicio la supremacía del Ejecutivo sobre el Legislativo: 1) un sistema presidencialista basado en la Constitución; 2) un gobierno unificado, en el cual el partido gobernante controla la presidencia y ambas cámaras del Congreso; 3) la disciplina al interior del partido gobernante; 4) un presidente que es líder reconocido del partido gobernante.

Se puede entender entonces que el predominio del Ejecutivo sobre otros centros de poder institucionales, y entre ellos el Legislativo por supuesto, estuvo cimentado en el control que ejerció sobre su partido, ya que la gran mayoría de los legisladores eran miembros del PRI y sabían que si se oponían a los intereses del presidente, las posibilidades de éxito en sus carreras políticas eran nulas, por lo que la estrategia predominante era la alineación de intereses con el Ejecutivo. El presidencialismo mexicano sustentó sus bases en una serie de arreglos institucionales que generaron una distribución del poder inequitativa e inclinada en favor del Poder Ejecutivo. Estos arreglos institucionales y las facultades metaconstitucionales del presidente resultaron ser muy efectivos para dar preeminencia al Ejecutivo, porque

8 Weldon Jeffrey, No-Reelection and the Mexican Congress, propuesta de disertación doctoral, San Diego, Universidad de California, 1991, p. 56. 
éste, gracias a la prohibición de la reelección legislativa inmediata, pudo definir el comportamiento de los actores políticos.

Esta situación llevó a que el Legislativo fuera, durante todo el régimen priísta, una entidad dependiente del Ejecutivo, ya que éste generó y reguló en su favor, una serie de mecanismos e incentivos que le permitieron invadir de manera exitosa al Poder Legislativo. Dichos incentivos que condujeron a la subordinación del Congreso partieron de 2 factores: el primero fue la capacidad que tuvo el presidente para determinar quienes iban a ser legisladores en el Congreso y el segundo se refiere al que tiene que ver con el manejo de los incentivos que generó la no reelección inmediata, el presidente de la República logró que los intereses de los congresistas se alinearan a sus preferencias, ya que éste ejercía de manera monopólica el control sobre el reparto de los curules y por consecuencia el control sobre la continuidad de las carreras políticas de los legisladores. Todo ello generó sino de manera formal pero sin duda real, la abdicación del Poder Legislativo a las facultades formales que hubiesen permitido una más efectiva división de poderes, y renunció de esta manera a ejercer sus funciones representativas, de tal forma que los legisladores se desempeñaron como aliados permanentes del presidente. "La estructura de incentivos mostró con claridad que el Congreso no iba a ser el lugar para impulsar iniciativas, ganar batallas o servir a los electores. El Congreso sería la arena indisputada del Ejecutivo a través del control sobre su composición y la conducta de sus integrantes". ${ }^{9}$

Con Lázaro Cárdenas se inauguraron los periodos sexenales de gobierno (1934-1940) Cárdenas fue el primer candidato presidencial que pudo intervenir en la conformación de las listas de candidatos de su partido para ocupar escaños en el Congreso de la Unión. A partir de entonces, esta sería una atribución cuasi exclusiva del Presidente de la República, sus sucesores repetirían esa práctica de manera irrenunciable, y la ejercerían de manera vital, ya que constituía parte de su fuerza como actor político. ${ }^{10}$

Cuando la no reelección legislativa inmediata era inexistente, la nominación de candidatos recaía en los mismos legisladores y en los jefes políticos

9 Casar, María Amparo, "Las relaciones entre el Poder Ejecutivo y el Legislativo: el caso de México", Política y Gobierno, México, vol. VI, núm.1, enero-junio de 1999, p. 6.

${ }^{10}$ Carpizo MacGregor, Jorge, Nuevos estudios constitucionales, México, Porrúa, 2000, p. 310. 
locales, con la restricción recaía en quien ostentara la titularidad del Poder Ejecutivo por medio de su partido,

la rotación de cargos puso en manos del Ejecutivo y de su partido, instrumentos poderosos para sancionar y premiar el comportamiento de los políticos en el Congreso. Con la no reelección inmediata, el partido dominante en el Congreso se convirtió rápidamente en una mayoría gobernante leal y obediente que dio estabilidad política al régimen en su conjunto. ${ }^{11}$

Así pues, ese sistema basado en la centralización del poder en la figura del presidente de la República ya no existe y ya no existirá. Es menester, por tanto, en coherencia con el espíritu original de los principios de la República —no los principios de ningún partido político — redistribuir el poder en los espacios institucionales y ciudadanos que les corresponden; es cierto que antaño las elecciones se veían afectadas por las prácticas de fraude electoral, pero en estos momentos el país viene adecuando sus leyes electorales dando mayor confianza a los ciudadanos, garantizando procesos limpios en el que se respetan las preferencias electorales. Es por eso que si queremos un Congreso más fuerte y activo, tendremos que reconocer que la prohibición de reelegir a los diputados y senadores conspira contra el desarrollo y maduración de nuestro Congreso; ya que bajo la sensibilidad, conocimientos y experiencia del legislador es donde se encuentran las bases del buen legislar, por ello, el pueblo quien eligió a sus representantes es quien debe juzgar si el legislador cumplió cabalmente con su responsabilidad y si así fuere, entonces el sufragio encontrará los mecanismos de expresión del mandato de la voluntad de sus electores. Hoy contamos con un sistema electoral competitivo, que a decir del maestro José Woldenberg: "no es posible lograr que un proceso electoral este exento de irregularidades y fraudes, pero para atajarlos y perseguirlos se han construido instituciones y mecanismos a lo largo y ancho del Estado". ${ }^{12}$

La reelección legislativa inmediata es hoy un tema de gran interés ya que revive el debate sobre su gran importancia. Académicos y políticos se han expresado al respecto, así por ejemplo:

11 Nacif, Benito, "Para comprender la disciplina de modelo de partido en la Cámara de Diputados de México: el modelo de partido centralizado", Foro Internacional, México, núm. 1, enero-marzo de 2002, p. 23.

${ }^{12}$ Herrera, Jorge, "IFE: utópico, pensar en la extinción del fraude", El Universal, México, año LXXXVII, t. CCCXLV, núm. 31, 100, 18 de febrero de 2003, p. 47. 
El politólogo español Joseph Colomer señala que para fortalecer al Poder Legislativo, es necesario que se permita la reelección de los legisladores en forma inmediata "si no es así, siempre habrá un Congreso que estará controlado por unos poquísimos individuos, que como ocurre ahora, y en un conjunto será muy débil". ${ }^{13}$

Por su parte el doctor Jorge Carpizo $;{ }^{14}$ se ha expresado en favor de la reelección,

pero sólo de legisladores, ya que no se debe abrir por ningún motivo al presidente de la República, porque se ha visto en México que la reelección del presidente sólo ha terminado con la muerte o con el derrocamiento de quien está en esa situación, no podemos repetir los errores del pasado. ${ }^{15}$

El gobierno federal, en su proyecto para la reforma del Estado de 2002 llamado "Conceptos Generales para la reforma del Estado" señaló que:

Las cámaras mexicanas son deficientes y muy poco institucionalizadas al comparárseles con democracias mejor establecidas, la deficiencia en su desempeño no se debe a su tamaño, ya que se trata de cámaras integradas por cientos de legisladores novatos, que desconocen las prácticas parlamentarias y los métodos de división de trabajo, delegación de responsabilidades y organización en comisiones. La clave del problema está en la inexperiencia y no en el número. Las cámaras mexicanas serán más fuertes y eficientes cuando se integren por cientos de legisladores experimentados. ${ }^{16}$

Como podemos observar, la reelección inmediata de los miembros del Congreso de la Unión es una necesidad para el gobierno federal desde hace varios años, ya que ante cualquier otra cosa, ésta constituiría una devolu-

13 Colomer, Joseph. "Reflexiones sobre la reforma política en México", Centro de Investigación y Docencia Económicas, México, 2003, p. 17.

14 Véanse también entre otros a González Oropesa, Manuel, “¿Qué hacer con el Congreso de la Unión?", Memoria del Tercer Congreso de Derecho Constitucional, México, UNAM, 1987, t. II; Hidalgo, Arturo, "Académicos a favor de la reelección legislativa sucesiva", Reforma, México, año 10, núm. 3115, 7 de mayo de 2005; Moreno Collado, Jorge, El debate en torno a la reelección de los diputados y senadores, México, PorrúaLVI Legislatura, Cámara de Diputados, 1996.

15 Teherán, Jorge, "El ex procurador Carpizo advierte sobre las reformas a la Constitución”, El Universal, México, año LXXXVII, t. CCCLXV, núm. 31, 108, 26 de febrero de 2005.

16 http:/www. Presidencia .gob. mx/abril del 2002. 
ción efectiva de poder a los ciudadanos que les fue retirado con la ilógica reforma de 1933 en aras de la estabilidad interna del partido dominante, restablecer la reelección inmediata para los legisladores es muy importante, ya que es el único instrumento que tiene la ciudadanía para lograr que sus representantes tengan presente de manera permanente que se deben a quienes votaron por ellos y no sólo a las cúpulas del partido que los apoyo en su carrera política.

\section{ARGUMENTOS EN FAVOR DE LA REELECCIÓN LEGISLATIVA INMEDIATA}

La reelección legislativa inmediata implicaría importantes beneficios para el fortalecimiento del Poder Legislativo Mexicano. Los legisladores que están en posibilidad de reelegirse se asumen en su función con mayor responsabilidad, ya que de su labor dependerá el continuar en su curul. Del mismo modo la posibilidad de reelegirse inmediatamente constituye un poderoso incentivo para el mejor desempeño del legislador, así Anthony Downs en su obra Teoría económica de la democracia ha señalado que "el interés primordial de los gobiernos y de los políticos no está dirigido, en primera instancia, hacia la consecución del bienestar público, sino que estos actores políticos están mayormente interesados en ganar elecciones, y por consecuencia, en ser reelectos las mayores veces posibles". ${ }^{17}$

Por su parte David Mayhew ha expresado que "el deseo de ser reelegido establece una conexión electoral muy fuerte entre los políticos que ofrecen sus servicios como agentes a sus electores para aumentar sus posibilidades de permanecer en el cargo". ${ }^{18}$ Así, la reelección legislativa inmediata adquiriría una connotación especial, ya que tomaría en cuenta el interés de la representación sobre el interés de los partidos. El legislador es representante de la nación y no representante del partido político por el cual llegó a su cargo, de tal manera que un candidato debe ser postulado por su partido, pero finalmente quien decide es el elector, en este sentido el partido político deberá tomar muy en cuenta al electorado al seleccionar al candidato.

17 Downs, Anthony, Teoría económica de la democracia, Madrid, Aguilar, 1973, p. 22.

18 Mayhew, David, Congress. The Electoral Connection, New Haven, Yale University Press, 1979, p. 45. 
Como lo han manifestado diversos especialistas, actualmente lo que sucede al iniciar una legislatura es que prácticamente se parte de la nada, de cero, porque son muy pocos los legisladores que repiten, y los que lo hacen, lo hacen por otro distrito electoral, integran una comisión distinta y en muchos casos empiezan por sí mismos a crear sus propias iniciativas olvidando los registros de lo ocurrido en la anterior legislatura, desaprovechando el trabajo y la experiencia acumulada, por lo cual, el esfuerzo de una legislatura se queda en el olvido al llegar la nueva, y en consecuencia el arribo a consensos se vuelve trabajoso y en ocasiones torpe, ante esta situación no podemos pedir mucho; exigimos legisladores experimentados y bien preparados, atentos a los ciudadanos, pero no les exigimos jamás volver a pedir el voto por el mismo cargo, ya que nuestra Constitución prohíbe la reelección inmediata de los miembros del Poder Legislativo.

En suma, con la reelección legislativa inmediata el Legislativo sería un contrapeso más eficaz al Ejecutivo; ya que el Poder Ejecutivo estaría sujeto al control del Legislativo en un sano equilibrio de poderes, el trabajo legislativo seguiría su marcha, los legisladores realizarían un trabajo más eficaz que no se vería truncado, los electores tendrían la posibilidad de exigirles cuentas a sus electores y en caso de tener un diputado o senador un buen desempeño, podrían los ciudadanos refrendar su confianza en él mediante la reelección, con ello ganaría la democracia ya que no se le podría coartar al electorado su derecho de elegir y reelegir libremente a quien desee que lo represente; de esta manera los partidos políticos disminuirían su poder discrecional de elegir a sus candidatos, ya que con la posibilidad de reelección inmediata de los legisladores los partidos forzosamente deberán tomar en cuenta el sentir de los electores, de lo contrario estarán destinados al fracaso electoral.

\section{La profesionalización y especialización del legislador}

En la política, como en toda actividad humana, existen incentivos que moldean el comportamiento de los individuos. Para un político que ha accedido al poder, la posibilidad de permanecer en él es un estímulo importante para su buen desempeño. Como dice Giovanni Sartori, "un político profesional es aquélla persona que se ocupa de manera estable de la política. Por lo tanto, en el ámbito legislativo, no son políticos profesionales los que se ocupan de forma ocasional o durante un periodo limitado de tiempo de la acción 
parlamentaria". ${ }^{19}$ Como podemos ver, la no reelección altera la lógica de la política, cuyo fin intrínseco es acceder al poder y mantenerlo. La limitación constitucional de la reelección inmediata de los legisladores al Congreso de la Unión, ha generado que en la práctica el programa legislativo lo realice en gran medida el Poder Ejecutivo, ya que los problemas de legislación son cada día más difíciles y requieren conocimientos especializados y actuales. Dicha profesionalización que generalmente no puede exigirse a los miembros del Congreso, se ubica en los organismos administrativos.

Lo anterior se debe entre otros factores, a que la amplia disponibilidad de recursos con que cuenta el Poder Ejecutivo hace más atractivo a los políticos querer pertenecer a ese poder, ya que representa una vía más eficaz de acceso al poder, estabilidad y con mejores perspectivas de profesionalización, ello ha traído como consecuencia que al Legislativo lleguen personas con menor perfil y preparación. Es decir, la no reelección legislativa inmediata ha generado una ventaja más para el Ejecutivo en el aspecto de ser una mejor opción de captación de personal más calificado dadas las mejores perspectivas e incentivos que ofrece; los funcionarios de alto nivel e incluso medio, son funcionarios que cuentan con mejor perfil académico y profesional que los legisladores, y ese hecho junto con la no reelección inmediata legislativa repercute directamente en la calidad del trabajo de cada rama del poder. En consecuencia, en México no se han desarrollado cuadros de legisladores que entiendan las complejidades de los programas y actividades gubernamentales de manera suficiente parar dar continuidad a la política legislativa. Esta insuficiente profesionalización provoca a su vez dependencia y debilidad del Congreso frente al Ejecutivo, factor importante del desarrollo democrático del país.

Por lo cual es importantísimo para el fortalecimiento de un Congreso, la experiencia que adquiere el legislador. Como nos lo señala el doctor Alonso Lujambio:

El legislador al permanecer mayor tiempo en su curul, como consecuencia del respaldo de su partido y del apoyo de sus electores obtiene ventaja sobre el resto en el sentido de que el legislador que ha hecho su trabajo y ha logrado reelegirse en dos o tres ocasiones acumula experiencia, conoce la materia hasta convertirse en un perito de la misma, se especializa en algunos campos

19 Sartori, Giovanni, Ingeniería constitucional comparada, 4a. ed., México, Fondo de Cultura Económica, 1999, p. 190. 
de la acción parlamentaria vía su participación en comisiones legislativas, fortalece a la institución. ${ }^{20}$

Es cierto que si un legislador repite en su cargo es muy probable que le dé mayor continuidad a sus proyectos y desarrolle un conocimiento superior al de muchos candidatos que nunca han ocupado el cargo. Los espacios en los que desde mi punto de vista se podría dar esta especialización son en las comisiones. Teóricamente podemos señalar que los legisladores buscarán estar presentes en las comisiones más importantes para su electorado; por ejemplo legisladores de los estados de Oaxaca, Chiapas, Michoacán, Guerrero buscarán estar en las comisiones de agricultura y ganadería, asuntos indígenas, atención a grupos vulnerables, desarrollo rural, desarrollo social, derechos humanos de sus respectivas cámaras porque esos son los temas más relevantes, más importantes para su electorado. Por lo tanto, se preocuparían y esforzarían por estar ahí, se especializarían en los temas que son de mayor trascendencia para su electorado y se profesionalizarían. Sobre el mismo respecto el doctor Benito Nacif nos menciona que:

La rotación regular de cargos en el Congreso destruye casi todo aquello que el sistema de Comisiones busca proteger: la especialización, la acumulación de experiencia y la independencia. No existen posibilidades reales de que las Comisiones se conviertan en cuerpos legislativos especializados en determinadas áreas cuando sus miembros ni siquiera se especializan en ser legisladores. ${ }^{21}$

Luis Carlos Ugalde en relación a la no reelección en la Cámara de Diputados nos dice que:

La no reelección consecutiva afecta el perfil de los Diputados porque obstruye la experiencia legislativa, desincentiva la especialización al interior de la Cámara y obstruye el reclutamiento de cuadros con calidad profesional, cada tres años la cámara tiene que re-inventarse a sí misma 500 Diputados dejan de serlo y emprenden la búsqueda de nuevos cargos políticos, mientras que simultáneamente 500 novicios asumen el control de la Cámara. ${ }^{22}$

${ }^{20}$ Lujambio, Alonso, "La reelección de los legisladores: las ventajas y los dilemas", Quórum, México, enero de 1996, p. 23.

21 Nacif, Benito, op. cit., p. 30.

22 Ugalde, Luis Carlos, “La reelección en México”, Nexos, núm. 47, mayo de 1992, p.3. 
Por todo lo anterior es indispensable la reelección legislativa inmediata. Ya no es posible contar con diputados y senadores cada tres y seis años respectivamente ya que cuando el Congreso de la Unión renueva completamente a sus legisladores "el cultivo de relaciones personales interpartidarias parte otra vez prácticamente de cero, con lo cual la acción legislativa y el arribo a consensos se vuelve trabajoso y torpe". ${ }^{23}$

Los legisladores no pueden ser eternos amateurs que cada tres y seis años ensayan con el destino de la Nación, es ya tiempo de que los legisladores produzcan leyes de calidad, necesitamos legisladores capaces, profesionales, verdaderos especialistas, ya no podemos mantener un Poder Legislativo débil, la misma Ley Orgánica del Congreso General de los Estados Unidos Mexicanos modificada por última vez en este aspecto en 1999, establece en el título segundo "de la Organización y Funcionamiento de la Cámara de Diputados", artículo 15, fracción I, que "para la conducción de la sesión constitutiva de la Cámara habrá una mesa de decanos, constituida por un Presidente, tres Vicepresidentes y tres Secretarios". El segundo párrafo establece:

La mesa de decanos se integra por los Diputados electos presentes que hayan desempeñado con mayor antigüedad la responsabilidad de legislador federal...el Diputado electo con mayor antigüedad será el Presidente de la mesa de decanos. Serán Vicepresidentes los Diputados electos que cuenten con las siguientes antigüedades, procurando reflejar la pluralidad de la conformación de la Cámara. En calidad de Secretarios les asistirán los siguientes tres Diputados electos que cuenten con las sucesivas mayores antigüedades.

De lo anterior damos cuenta que la propia ley contempla la participación de los miembros más experimentados en tareas legislativas tan importantes como lo es la Sesión Constitutiva de las cámaras, lo que constituye la necesidad de profesionales en el que hacer parlamentario y que aún el Congreso de la Unión no cuenta con ellos. Sin embargo y siendo totalmente objetivos debemos de reconocer que como dice Dworak:

La permanencia en el cargo no es suficiente para que un legislador quiera especializarse en algún tema. Los individuos focalizarán sus energías en aquellas actividades que maximicen sus posibilidades de ascender en el sistema político. De tal manera que la especialización podría, o no, ser un

23 Idem. 
medio y dependerá de variables como los procesos de elección y selección de candidatos, la estructura de los partidos, las oportunidades que ofrezca el sistema político, la institucionalización interna de una legislatura y los intereses personales. ${ }^{24}$

Si bien es cierto que nada garantiza la completa profesionalización ni la especialización de los legisladores, así como ninguno otro de los beneficios y ventajas que derivarían de la reimplantación de la reelección legislativa inmediata ya que no puede preverse todo y siempre existe la posibilidad de que surjan problemas, inconvenientes o imprevistos, así como que también se tienen que tomar en cuenta otros factores de carácter subjetivo como disposición, actitud, ambición de los legisladores, etcétera. También lo es el hecho que de seguir las cosas como están, como ocurre ahora será prácticamente imposible que haya una profesionalización y especialización, ya que los legisladores ni siquiera tendrán la oportunidad de hacerlo al no haber estabilidad y continuidad en el trabajo, asimismo no debemos ver esta reforma como la salvadora de todos nuestras deficiencias legislativas, ni debemos de pensar que con ella se resolverán todos nuestros problemas de la noche a la mañana o que la misma nos proporcionará legisladores hábiles y expertos automáticamente, los resultados de esta reforma no serán inmediatos, sino paulatinos, graduales, además no debemos de olvidar que ni en México ni en ninguna parte del mundo se producen o se producirán reformas perfectas todas tienen un costo a pagar, lo importante es minimizar en lo posible esos efectos negativos y no tener miedo, además de estar conscientes de que de no llevarse a cabo esta reforma muy probablemente no contaremos nunca con un Poder Legislativo fuerte, profesional, eficiente, eficaz, acorde a las necesidades y demandas que un país como el nuestro requiere.

\section{Rendición de cuentas y democracia}

Bernard Manin ${ }^{25}$ afirma que "es el rendimiento de cuentas lo que ha constituido desde el principio el componente democrático de la represen-

24 Dworak, Fernando (coord.), El legislador a examen, el debate sobre la reelección en México, México, Fondo de Cultura Económica-Cámara de Diputados, 2002. p.15.

25 En el mismo sentido véase a Dahl, Robert, La poliarquía: participación y oposición, 2a. ed., Madrid, Tecnos, 1997; Schmitter, Phillipe, Transiciones desde un gobierno autoritario, Barcelona, Piados, 1994, vol. 2: América Latina; Dahrendorf, Ralf, La democracia en Europa, trad. de Diana Zegarra, Madrid, Alianza, 1993. 
tación. Y la representación actual aún contiene ese momento supremo en el que el electorado somete a juicio las acciones pasadas de los que están en el gobierno". ${ }^{26}$

Como podemos observar la rendición de cuentas es un elemento fundamental de la democracia moderna, la cual se encuentra ausente en el Poder Legislativo Mexicano ya que los votantes no pueden responsabilizar a los legisladores por sus acciones, lo más que pueden hacer es castigar al partido. Como hemos visto la reelección es un incentivo muy poderoso para que los congresistas actúen en beneficio de sus representados. Ésta propiciaría que las elecciones fueran un verdadero mecanismo para estimular la responsabilidad de los gobiernos, los electores ejercerían sanciones al no reelegir al partido en el gobierno o castigarían a un representante negándole un segundo periodo; en este esquema el elector es el vigilante último, la posibilidad de la reelección permite que sea el electorado y no las dirigencias nacionales de los partidos políticos quienes juzguen los actos de sus diputados y senadores, esta manera de proceder es de vital importancia en una democracia ya no digamos moderna sino verdadera ya que de no adoptar este modelo y aunado "al hecho de que cada tres años se deben postular nuevos candidatos, permite la intromisión del Presidente de la República en el proceso; hecho que a su vez reduce el grado de responsabilidad de los diputados y senadores frente a sus electores". ${ }^{27}$

E1 doctor Luis Carlos Ugalde, ${ }^{28}$ ha definido esta anomalía con la hipótesis de la responsabilidad invertida:

En México la no reelegibilidad diluye el nexo electoral que se supone debe haber entre representantes y representados, y por consiguiente también disminuye el grado de responsabilidad política o rendición de cuentas de los legisladores para con sus electores. Paralelo a este fenómeno ocurre otro en sentido inverso que estimula y aumenta la responsabilidad de los legisladores, pero frente al Presidente de la República y a su partido. La dirección de la responsabilidad política se invierte, de los votantes hacia el jefe del

26 Manin, Bernard, Los principios del gobierno representativo, 3a. ed., trad. de Fernando Vallespín, Madrid, Alianza, 2006, p. 32.

27 Ugalde, Luis Carlos, Vigilando al Ejecutivo, México, Porrúa-Cámara de Diputados, 2000, p. 51.

28 En el mismo sentido véase Crespo, José Antonio, "Reelección parlamentaria", Este Pais, México, núm. 86, mayo de 1998; Rubio, Luis, México: democracia ineficaz, México, Cámara de Diputados, 2006, 
Ejecutivo. Esta vinculación es el resultado de las facultades de promoción política del Ejecutivo (y de su partido) para recompensar a los legisladores con nuevas candidaturas, ya sean en el orden federal, estatal o municipal o bien con cargos en la administración. ${ }^{29}$

Así pues, con la reelección legislativa inmediata los votantes podrán evaluar si deben recompensar a sus legisladores y reelegirlos o si por el contrario deben castigarlos y votar a su competidor u opositor, es decir la rendición de cuentas debe ser interpretada como la obligación legal y ética que tiene un representante de informar a sus representados como ha utilizado el dinero y otros recursos que le fueron dados por el pueblo para emplearlos en beneficio de todos y no en provecho de sí mismo y en medio de ello el servidor público deberá de responder públicamente por la eficacia de su gestión con base en resultados concretos; así entonces la relación entre el representante y sus representados se mantiene e incentiva porque el legislador sabe que al concluir el periodo para el que fue electo deberá volver y rendir cuentas a sus representados si quiere permanecer en su puesto. Este pues es el esquema normal de responsabilidad que impera prácticamente en todo el mundo a excepción de Costa Rica y por supuesto México. En nuestro país, desgraciadamente la no reelección presidencial es un principio antidemocrático para preservar la democracia ante el inmenso poder que concentra el Ejecutivo, sin embargo en el caso del Poder Legislativo la reelección no debe verse como un privilegio del diputado federal o senador, esta prohibición como hemos venido observando en el desarrollo del presente escrito en el Legislativo no tiene razón de ser.

En otras democracias mejor consolidadas la reelección legislativa inmediata no es vista como un privilegio del diputado o senador, sino por el contrario es vista como un atributo personal del ciudadano para premiar la labor efectiva de su representante; o bien, para castigarlo si no lo representó diligentemente, en México debemos adoptar esta posición, debemos permitir la reelección legislativa inmediata para que el ciudadano común y corriente juzgue a su legislador, lo evalúe y lo premie con la reelección o lo castigue no otorgándole su voto para la próxima elección, no debemos olvidar que la reelección sirve no sólo para permitir la continuidad de los legisladores sino para cambiar a los malos legisladores, y bueno un legislador que no es refrendado por su electorado es un legislador políticamente muerto ya que

29 Ugalde, Luis Carlos, op. cit., p. 80. 
difícilmente podrá volver al Congreso e incluso a otro puesto de elección popular, es un escollo difícil de superar, sin embargo ¿cómo desear esto, si como ciudadanos no sabemos la labor que desempeña nuestro legislador? Para estar en condiciones de participar en los asuntos públicos debemos saber qué es lo que está pasando con nuestros representantes; los legisladores deben acudir a informar su labor al electorado que les otorgó su confianza, a darse cuenta de las necesidades y las preocupaciones de sus distritos. De esta forma, al ser el legislador un representante, debe tener el estímulo que le permita representar con verdadero vigor a sus representados, frecuentar a sus electores, a los ciudadanos que les otorgaron el voto, debe entonces tener interés por conocer sus problemas y llevarlos a tribuna mediante propuestas que favorezcan a sus representados. Ello sólo se logrará si el legislador rinde cuentas al elector y tiene como estímulo la posibilidad de poder reelegirse de manera inmediata.

Así, el legislador que trabajó, que verdaderamente cumplió con su electorado, sabe que puede ser respaldado en la siguiente elección, como lo explica Nicolás Maquiavelo en su obra el Príncipe: “el poder es ejercido por alguien del pueblo y para el pueblo... un príncipe debe hallar una manera por la cual sus ciudadanos siempre y en toda ocasión tengan necesidad del Estado y de él, pues así le serán siempre fieles". ${ }^{30}$ De modo que la estrategia que tienen los buenos actores políticos para que su electorado los necesite y siga votando por ellos y por su partido es trabajar, pero trabajar verdaderamente, dando resultados, eficazmente y ello lo debe evaluar el electorado, para así refrendarlo con su voto.

Ahora bien por lo que toca a la democracia, hemos visto que la rendición de cuentas por parte de los funcionarios públicos a sus electores, constituye un presupuesto básico para entender cabalmente el concepto de democracia y para considerar que un Estado efectivamente se considera democrático si sus ciudadanos tienen la posibilidad de evaluar periódicamente a sus representantes, de lo contrario como ocurre en México, tendremos un Estado formal y constitucionalmente democrático, pero en los hechos, en la realidad tendremos un Estado con democracia aparente, inacabada e inmadura lo cual obviamente debilita al Estado mismo y a sus instituciones, dicho lo anterior pasemos ahora a examinar lo relativo al concepto democracia en nuestro México.

30 Maquiavelo, Nicolás, El príncipe, 23a. ed., México, Porrúa, 2005, p. 45. 
La voluntad del pueblo mexicano ha sido constituirse en una forma de gobierno democrática. Y la democracia reconoce igualdad de oportunidades entre los hombres, por lo cual el pueblo debe ejercer una vida equitativa y plena en sus derechos políticos y civiles; así el ciudadano en un país que se considere democrático tiene la libertad de elegir a quien él considere apto y debe estar en posibilidades de reelegir, con todo derecho político al legislador que ha cumplido con sus expectativas.

Nuestra Constitución considera a todos los hombres iguales en libertad y derechos; si el estandarte político y democrático revolucionario fue el "sufragio efectivo y la no reelección", esta última frase "no reelección" se debe acatar por razones históricas perfectamente fundadas en el titular del Poder Ejecutivo, no así en los miembros del Poder Legislativo ya que si Porfirio Díaz se perpetúo en el poder por más de tres décadas lo pudo hacer no por la posibilidad de la reelección sino por la ausencia de un sufragio libre y universal. Cuando el sufragio no es efectivo, como no lo fue durante los más de 70 años de hegemonía priísta, efectivamente la no reelección parecía constituirse como el único mecanismo real para limitar a malos gobernantes en el poder. Pero ello no servía para impedir que otros malos gobernantes llegaran al poder. Peor aún: la no reelección actúo como un mecanismo perverso que fomentó el saqueo de las arcas nacionales. Obviamente, el hecho de que no existiera una rendición de cuentas efectiva actuaba como un incentivo para esta conducta, así pues; una vez aclarado el espíritu del lema revolucionario considero que debe operar la reelección legislativa inmediata de los legisladores, pero acotada, para que sea la propia voluntad popular por medio de elecciones periódicas y reales la que exprese su confianza en el legislador, y de ser así refrendarle el voto. Serían entonces los ciudadanos quienes reconocerían y juzgarían, en un momento dado quien es el mejor para representar a la nación.

Entonces, ante la eventual contienda para la reelección, el mal legislador estaría expuesto después de una función reprobable a un voto de censura; esto conlleva a explicar que cualquier disposición tendiente a la reelección no implica necesariamente la consumación de ésta, pues aún cuando la labor haya sido brillante como parlamentario nada le asegura volver a ocupar el cargo, puesto que queda a la exclusiva voluntad de los electores, lo trascendental en este asunto es precisamente que el principio de no reelección desfavorece la única oportunidad a disposición de los ciudadanos para calificar a sus representantes. 
Así pues, lo fundamental en la legitimación es que el poder de un gobernante o legislador este cimentado en el pueblo, sólo así se tiene la dignidad de representar auténticamente a su comunidad, por ello, el vínculo del legislador con sus electores debe ser constante y directo, de esta manera el legislador tendrá autoridad, tendrá presencia, así es el propio legislador quien debe legitimar su autoridad ante sus electores, el legislador buscará mantenerse en su curul y sólo lo podrá hacer mientras el electorado así lo decida.

Por ello debemos permitir la reelección inmediata de los legisladores, no privar a los ciudadanos de su derecho de evaluar y mantener a sus buenos legisladores o de remover a los que no sirven, no debemos olvidar que la reelección también sirve para esto, para remover a los incompetentes.

Ahora bien, para entender cabalmente estas ventajas no se puede perder de vista la confianza que hoy se tiene en los órganos encargados de organizar las elecciones, y en la transparencia de los procesos comiciales. Mientras que, como señala Jesús Silva Herzog-Márquez: "la reelección en un régimen autoritario significa la momificación de la clase política, en otro, en etapa transicional o de democracia emergente, puede ayudar significativamente a la autonomía del Poder Legislativo, y al mejoramiento de la representación política". ${ }^{31}$

Sin embargo y a pesar de todos las ventajas que conllevaría la reelección legislativa inmediata; por razones sobre todo históricas y quizá también por la mala percepción que se tiene de los poderes públicos ante la sociedad, las encuestas demuestran que la reelección legislativa inmediata no es una medida vista con buenos ojos por la sociedad. Así, por ejemplo, el Centro de Estudios Sociales y de Opinión Pública adscrito a la Cámara de Diputados de nuestro H. Congreso de la Unión publicó en el mes de marzo de 2004 los resultados que arrojaron una de sus encuestas nacionales relativa a la opinión, a la percepción que tiene la sociedad ante la posible reimplantación de la reelección inmediata de nuestros legisladores federales; así, dicha encuesta reveló que la reelección legislativa inmediata no es aceptada por la gran mayoría de la sociedad (75\%), esto se debe entre otros factores al escaso conocimiento sobre el tema que se tiene entre la población, ya que al explicarles algunas de las ventajas que ésta reportaría el porcentaje de desaprobación disminuye en un índice importante(17\%-25\%) y en consecuencia los índices de aprobación se elevan considerablemente (45\%). Asimismo,

31 Silva-Herzog Márquez, Jesús, El antiguo régimen y la transición en México, México, Planeta, 2003, p. 31. 
otro factor importante que explica el rechazo a esta reforma es el escaso conocimiento entre la población de la labor legislativa y el desprestigio y poca credibilidad que tienen los legisladores ante la opinión pública por los razones de sobra conocidas por todos y finalmente un factor que no hay que olvidad y que por el contrario hay que tener muy presente, es el relativo a que el principio de no reelección sigue aún muy arraigado entre la población y es visto como uno de los pilares sobre los que descansa nuestro sistema político y nuestra incipiente democracia. Para concluir este punto, cabe resaltar el hecho de que si bien en una primera instancia la reimplantación de la reelección legislativa inmediata es rechazada por un amplio margen de nuestra población; también lo es el hecho de que al explicarle a la ciudadanía las ventajas y beneficios que ésta traería los porcentajes de aprobación se incrementan considerablemente por lo que cabe mencionar que en general los ciudadanos están en favor de todos aquéllos cambios que tiendan a mejorar el desempeño de los legisladores, pero para que esta reforma no sea vista como un regreso al pasado y se asocie a la dictadura que propicio la reelección del Ejecutivo, es necesario realizar una amplia campaña de divulgación social en todo el país en el que se explique a la sociedad el verdadero sentido de esta reforma, los objetivos que se persiguen con la misma y los beneficios que ésta reportaría y dejarles muy en claro que no se trata de darle más poder a los legisladores sino por el contrario se trata de devolverle el poder a los electores de llamarlos a cuentas, exigirles resultados y como consecuencia de ello decidir si los castigan negándoles la reelección o por el contrario los premian con la misma.

\section{Fomento de relaciones interpartidarias}

Gran parte de la responsabilidad política en la falta de acuerdos parlamentarios que padece nuestro país tiene su explicación - no justificación —en la falta de un cultivo cuidadoso de las relaciones interpartidarias, que se facilitarían con la experiencia parlamentaria que se le otorga a un representante responsable sometido a sus ciudadanos. ${ }^{32}$

32 Andrea Sánchez, Francisco José de, "Reelección legislativa consecutiva: una iniciativa de reforma riesgosa", Boletín Mexicano de Derecho Comparado, México, núm. 103, enero-abril de 2002, p. 35. 
La ubicación de coincidencias entre quienes piensan diferente y la construcción de consensos pueden ser más sencillas y efectivas con la experiencia parlamentaria, si la población tiene a salvo la prerrogativa de sancionar a sus diputados y a sus senadores, desaparecerán la irresponsabilidad parlamentaria, los espectáculos grotescos o las frivolidades que, por ahora, no tienen castigo popular.

El doctor Lujambio nos señala que con el esquema actual, con la renovación completa de los integrantes del Poder Legislativo al terminar el periodo para el que fueron electos:

El cultivo de relaciones personales interpartidarias parte otra vez prácticamente de cero con lo cual la acción legislativa y el arribo a consensos se vuelve trabajoso y torpe. En cambio, las relaciones armónicas entre cúpulas, bases y elites partidarias se ven auspiciadas cuando existe estabilidad de largo plazo en la composición de las cámaras legislativas, pues la frecuencia de trato, la experiencia, la preparación y el profesionalismo de cuerpos legislativos con menor tránsito eventual de individuos, permite la consolidación armónica de las relaciones de trabajo entre equipos indispensables para la labor legislativa y política. ${ }^{33}$

No debemos de olvidar que en cualquier democracia del mundo el capital político es un bien escaso, por lo que debemos cuidar y fomentar el cultivo de relaciones interpartidarias y esto se lograría en gran medida permitiendo la reelección inmediata de los legisladores.

\section{ARGUMENTOS EN CONTRA DE LA REELECCIÓN LEGISLATIVA INMEDIATA}

Una vez expuestos y analizados los principales argumentos en favor de la reelección legislativa inmediata, conviene del mismo modo analizar los posibles inconvenientes que la misma acarrearía si no se implementa bien, es decir como toda decisión política de este tamaño, la introducción de una reforma legislativa pro-reeleccionista no sólo generaría la posibilidad de los beneficios antes descritos, sino también como ya se había mencionado en páginas precedentes de ciertos costos políticos por lo que es necesario estar conscientes de ellos. Las consecuencias negativas que podría reportar la

33 Lujambio, Alonso, op. cit., p. 29. 
reelección inmediata de nuestros diputados y senadores si esta no se realiza adecuadamente, y acompañada de otros mecanismos a mi consideración se sintetizan en los siguientes argumentos: se cree que la reelección obstaculizaría la circulación de elites políticas y propiciaría relaciones de patronazgo, así como una vuelta al caciquismo local; tensiones entre el interés general y local; debilitamiento de la disciplina de los legisladores con respecto a sus dirigencias partidistas y finalmente que la reelección generaría condiciones ventajosas para los legisladores que quisieran, una vez concluido su periodo, volver a competir. Pasemos pues a analizar cada una de ellas.

\section{Enquistamiento y poca circulación de cuadros.}

Uno de los principales argumentos esgrimidos en favor de la no reelección, es que esta medida ha sido un instrumento normativo sumamente efectivo para evitar el continuismo y la formación de enclaves políticos al interior del Congreso de la Unión, los gobiernos estatales y las legislaturas locales. Para muchos el principio de no reelección propició una buena circulación de elites al entrar en la vida política nacional nuevas y constantes generaciones de políticos jóvenes, o políticos que sin ser necesariamente jóvenes han tenido oportunidad de participar en la conformación de la representación política del país gracias a la constante renovación de cuadros.

Este argumento continúa siendo lo suficientemente válido para la clase política mexicana e implica a la vez, que la no reelección no sólo provoca una obligatoria rotación de cuadros, sino que además hizo de éste un nuevo principio político, mucho más vigente y legítimo que el de la rendición de cuentas.

Así pues, durante mucho tiempo, proponer la reelección inmediata de los legisladores hubiese sido arriesgado puesto que no existía democracia electoral. Bajo este contexto la reelección sólo hubiese empeorado lo que en realidad quería solucionar. Sin democracia, en efecto, la reelección habría significado la ocupación permanente de los espacios legislativos por determinados individuos sin la posibilidad de renovarlos. Sin embargo, con democracia electoral, como la que vive México, la permanencia en el Congreso se encontraría sujeta al veredicto electoral, pero aún así hay que reconocer que no se elimina la posibilidad de monopolización temporal de los cargos legislativos. Aunque cabe dejar claro que no es cierto que todos los legisladores se perpetuarían en sus curules ya que la posibili- 
dad de la reelección no se ofrecería a todos los congresistas, sino sólo a los de mayoría y el resto si quisiesen reelegirse tendrían que competir por ese principio, además la posibilidad de reelección no garantiza de manera automática el triunfo electoral y en consecuencia no es posible sustentar que todos y cada uno de los legisladores van a reelegirse, además algunos querrán competir por una alcaldía, una gubernatura e incluso la Presidencia de la República. La reelección inmediata pues, no impide la circulación de cuadros, solo la hace más lenta pero genera competencia de más calidad, aquí se sacrifica la velocidad de la circulación y la cantidad de nuevos cuadros, por la calidad de los mismos.

El doctor Alonso Lujambio al tratar el tema cuestiona que si se permite la reelección " $i a$ la larga se enquistarían los legisladores en sus escaños?, la respuesta es sí, pero sólo una minoría". ${ }^{34}$ Por su parte Joseph Klesner en un estudio que realizó posterior a las elecciones legislativas intermedias de 1997 demostró que 41\% de los 300 distritos electorales de mayoría son ya claramente multipartidistas y $21 \%$ son bipartidistas, es decir, que prácticamente $62 \%$ de los distritos de mayoría en el país son plenamente competitivos y en ellos no se puede hablar con seguridad de la obtención del triunfo electoral por parte de ningún partido político. En consecuencia:

Tal vez entre 50 y 60 escaños de un total de 500 mantengan en el futuro a caciques inamovibles si se permite que los legisladores se reelijan ilimitadamente, ¿hay un costo a pagar por ello? sí, pero piénsese que el costo a pagar para mantener el principio de no reelección inmediata es infinitamente superior a la que representa mantener inamovibles en sus escaños a un puñado de caciques locales que, en última instancia, muchas democracias representativas han tenido que tolerar. ${ }^{35}$

Podemos señalar entonces, que la reelección consecutiva ilimitada sí impactaría en la circulación de elites, se puede prever que habría políticos que se mantendrían inmóviles en sus cargos, pero serían muy pocos; además no hay que olvidar que el hecho de que se puedan reelegir no implica que lo harán por siempre, y de hacerlo, sería una decisión de los votantes mantenerlos en el cargo, y por lo tanto su permanencia sería una decisión democrática. Tenemos entonces que con mucha facilidad se piensa que la reelección inmediata provocaría que casi automáticamente, al eliminar la res-

34 Ibidem, p. 34.

35 Ibidem, p. 36. 
tricción constitucional, se tendría como efecto inmediato que los legisladores buscarían su reelección, y que al conseguirla, se generaría un incremento en el número de legisladores que permanecerían en las cámaras, dando como resultado la perpetuación de un grupo importante de legisladores.

Sin embargo, en un interesante trabajo Rogelio Hernández Rodríguez ${ }^{36}$ se ocupó de estudiar y sustentar empíricamente los índices de reelección en la cámara baja durante el periodo en que la restricción constitucional no existía, es decir, estudia los índices de reelección consecutiva en México desde la promulgación de la Constitución de 1917 hasta 1934. En primera instancia podríamos suponer que al permitirse la reelección, los diputados se reelegían constantemente, sin embargo el citado autor presenta el siguiente cuadro para refutar la anterior aseveración:

\begin{tabular}{|c|c|c|}
\hline \multicolumn{3}{|c|}{$\begin{array}{c}\text { Reelección de diputados federales } \\
\text { (1917-1934) }\end{array}$} \\
\hline & Absolutos & $\%$ \\
\hline Con 1 legislatura & 1176 & 75 \\
\hline Con 2 legislaturas & 247 & 15.7 \\
\hline Con 3 legislaturas & 94 & 6 \\
\hline Con 4 legislaturas & 33 & 2.1 \\
\hline Con 5 legislaturas & 12 & 0.8 \\
\hline Con 6 legislaturas & 5 & 0.3 \\
\hline Con 7 legislaturas & 1 & 0.06 \\
\hline Total & 1568 & 100 \\
\hline
\end{tabular}

Estos datos demuestran que aún sin restricción la tasa de reelección es relativamente baja, lo que indica que el número de legisladores experimentados tan sólo representó una cuarta parte del total de diputados.

No obstante hay que reconocer y tener muy en cuenta que el contexto en el que operó la reelección no tiene nada que ver con el contexto en el que operaría en un futuro en caso de ser suprimida la restricción constitucional, por lo que las estadísticas de aquel periodo no debemos dejar de verlas como eso, como meras estadísticas y no debemos de caer en el error de creer que aquéllos resultados podrían extrapolarse o servir de fundamento para

${ }^{36}$ Hernández Rodríguez, Rogelio, La reelección en el Poder Legislativo en México, México, El Colegio de México, 1991, pp. 7-9. 
un escenario futuro dadas las complejas condiciones políticas del México actual, sin embargo, los resultados arrojados por la investigación son muy importantes para demostrar que todos aquéllos que suponen que la reelección inmediata generaría automáticamente un enquistamiento prolongado en nuestras cámaras no se basan más que en eso, en meras suposiciones ya que no hay evidencia sólida que respalde su dicho o al menos no la han hecho pública. Tales opiniones entonces, se basan en las experiencias negativas que han tenido otras naciones con la reelección inmediata de sus legisladores, que si bien es importante estudiarlas y tenerlas en cuenta; hay que tener presente también que existen otros factores que inciden directamente en el enquistamiento y poca rotación de cuadros al interior de las cámaras legislativas, tales como la posibilidad de que la reelección sea ilimitada o no, quién y cómo se financian dichas campañas, etcétera.

\section{Conflicto de intereses distritales y partidistas y eventual pérdida de la disciplina parlamentaria}

Ciertamente se esperaría que eventualmente sucediera una confrontación entre los intereses de los distritos que representen los legisladores y los intereses del partido nacional, lo cual colocaría al legislador ante una difícil decisión: ¿obedecer al CEN de su partido o a sus electores? No siempre podrá complacer a los dos, cada vez que esta situación se presentase tendrá que realizar un balance de costo-beneficio y tomar la decisión que más le convenga para su carrera política. Se podría pensar que de esta manera los comités ejecutivos de los partidos perderían el control sobre sus congresistas, pero este no es el caso. Si la reforma llegase a concretarse, los partidos políticos todavía seguirían siendo el único medio para competir por un cargo de elección popular. De tal manera que, si un legislador actuara contra el partido lo podrían castigar negándole el registro para su reelección.

Puede creerse del mismo modo que esta reforma haría que los diputados y senadores atiendan más a sus distritos, y con ello la disciplina partidista en el Congreso se vería relajada a niveles perjudiciales. Tal supuesto permite asumir también que puede presentarse una tensión periódica o sistemática entre los intereses del partido y los intereses del distrito electoral que represente el legislador. En México, sin embargo, hoy en día esta tensión no se presenta, pues la no reelección inmediata ha sido un instrumento muy efectivo para que tal divergencia de intereses no ocurra, ya que la misma 
ha permitido el alineamiento constante entre los intereses individuales de los legisladores y los de sus partidos, esto se debe a que los distintos partidos políticos se encuentran en una posición hegemónica con respecto a sus legisladores.

Desde luego el monopolio de las postulaciones de candidatos a cargos de elección popular que tienen los partidos, es el candado principal que contribuye a lograr esa unidad y disciplina partidista. Para ilustrar los efectos de la reelección inmediata legislativa en el Congreso, se ha utilizado mucho el ejemplo de los Estados Unidos, sin embargo habría que aclarar que en México el sistema de partidos difiere mucho del de los Estados Unidos; en ese país, los partidos políticos no son vistos como actores importantes dentro del ámbito legislativo, principalmente porque ellos no controlan el acceso a las boletas electorales debido a la institucionalización del sistema de elecciones primarias, que si bien existen en México éstas no son obligatorias, sino que dependen de la decisión de las dirigencias nacionales de los partidos. Además, el rol de los partidos en las campañas electorales tanto en términos financieros como logísticos, es mucho menor con respecto a los partidos mexicanos; ya que mientras en los Estados Unidos, al menos en lo que respecta al financiamiento de las campañas electorales los partidos políticos se han visto desplazados por importantes grupos de intereses económicos y políticos, En nuestro país el vínculo que la reelección legislativa inmediata estrenaría entre los electores y el legislador, disminuiría la importancia de algunas instancias intermedias hasta ahora ocupadas por los partidos, y daría a los legisladores una mayor libertad de acción frente a ellos. Se podría pensar entonces que la reelección debilitaría a los partidos políticos y que ello conllevaría a la indisciplina parlamentaria y a una fuerte dosis de incertidumbre en el proceso legislativo.

Sin embargo, el temor de que en México como en los Estados Unidos, la reelección inmediata fomente una desmedida independencia de los candidatos frente a su partido no es, como otros antes mencionados, un argumento totalmente sólido, pues nuestra legislación electoral vigente establece reglas que proporcionan elementos para que los partidos no se debiliten de manera alarmante y peligrosa. En primer lugar ningún político puede acceder a un cargo de elección popular sin el aval de un partido político, ya que no existe la figura de las candidaturas independientes. En segundo lugar, el sistema electoral mixto contribuye a no debilitar a los partidos, ya que si bien los legisladores electos en los distritos uninominales de mayoría relativa eventualmente pudiesen tomar posiciones 
distintas a las de sus partidos en determinados asuntos, y si esto es considerado como indisciplina, la representación proporcional por su parte, mantiene para las organizaciones partidistas el control absoluto de las nominaciones, por lo que al menos 200 diputados federales y 32 senadores se verían forzados a acatar las directrices de sus respectivos partidos pues sin ellos quienes los han postulado y quienes pueden seguir haciéndolo.

Otra arma importante con la que cuentan los partidos políticos para evitar una indisciplina alarmante es la referente al mecanismo de financiamiento de las campañas electorales, la cual está centralizada en los comités directivos de los mismos, y aunado al hecho de que los candidatos en lo individual no pueden conseguir legalmente recursos públicos para financiar sus campañas con independencia de sus partidos la disciplina esta forzada.

Otro factor que aseguraría la disciplina es la facultad que tienen los coordinadores parlamentarios de las distintas fracciones partidistas en las cámaras para asignar legisladores en las comisiones que consideran pertinentes. Este poder de nombramiento en las comisiones es algo que $\mathrm{Carey}^{37}$ contempla dentro del abanico de recursos y medios que tienen los líderes partidistas sobre los legisladores y los que el autor denomina como beneficios exclusivamente legislativos - dentro de estos beneficios Carey contempla la nominación para la reelección, financiamiento para campañas de reelección, asignación de oficinas y control o influencias sobre la agenda legislativa, etcétera- Estos líderes tienen en sus manos recursos para ampliar o disminuir las oportunidades políticas de los legisladores ya que cuentan con un enorme poder de distribución de recursos para premiar o castigar.

Como sabemos existen comisiones que interesan más que otras por el peso político que tienen. Pertenecer a comisiones importantes representa un incentivo para el legislador; ya que legisladores importantes pertenecen a comisiones importantes. Al respecto el doctor Benito Nacif señala que "en ausencia de continuidad en las carreras parlamentarias y de estabilidad en la composición de las comisiones, no es posible el desarrollo de instituciones que regulen el poder de los dirigentes de los grupos parlamentarios para asignar a los legisladores a Comisiones". ${ }^{38}$

Recapitulando de lo anteriormente expuesto, el hecho de que la legislación electoral mexicana establezca que los partidos políticos tienen el monopolio

37 Carey, John, "Discipline, Accountability and Legislative Voting in Latin America", en Albany, Comparative Politics, vol. 35, núm. 2, enero de 2003, p. 20.

38 Nacif, Benito, op. cit., p. 50. 
en la postulación para cargos de elección popular, que controlen de manera centralizada el financiamiento público para campañas y precampañas, aunado al principio de representación proporcional y al poder de los partidos por medio de sus coordinadores parlamentarios para asignar legisladores a las diversas comisiones son candados ya establecidos en el sistema electoral mexicano que obstaculizarían de manera importante el desbordamiento de un tipo de indisciplina o rebeldía de los legisladores con respecto a sus partidos y si bien es cierto que debido a las características de nuestro sistema electoral es posible que con la reimplantación de la reelección legislativa inmediata los partidos perderían cierto poder, éstos como hemos visto conservarían el suficiente para mantener la mínima disciplina que les exigiría la labor legislativa.

\section{Inequidad en la competencia por el cargo}

Un sólido argumento en contra de la reelección legislativa inmediata, gira en torno a la idea de que los legisladores que buscan reelegirse pueden acumular una serie de recursos provenientes del ejercicio natural de su encargo que los colocaría en una posición ventajosa con respecto a sus competidores, provocando en consecuencia que la competencia electoral se torne desigual. Estas ventajas de las que gozarían los políticos con la tenencia del cargo suponen de entrada, serios obstáculos a los nuevos competidores.

Así, los legisladores que buscan la reelección disponen de estructuras administrativas provenientes ya sea de su labor partidista o legislativa, cuentan con recursos logísticos como personal, oficinas, cierto financiamiento etcétera. A su vez, los medios de comunicación le ponen más atención a sus declaraciones, propuestas, proyectos, incluso a su vida personal aunado a lo anterior gracias a su cargo fomentan contactos políticos y tejen redes que son muy útiles para la negociación del apoyo electoral; todo ello se constituye en un conjunto nada despreciable de recursos sumamente valiosos e incluso decisivos, a la hora de enfrentar a sus adversarios políticos.

Desde mi punto de vista, es por esta serie de ventajas en favor de los legisladores que en muchos se genera el temor a la reelección inmediata, y es, considero, el temor o riesgo más fundado. Una vez más mucha de esta reticencia, de este miedo a la reelección entre los mismos políticos se basa en la experiencia de los Estados Unidos ya que si uno observa los patrones de reelección que se dan en el Congreso estadounidense, resulta evidente 
que un porcentaje enorme de legisladores permanece en su puesto en ocasiones hasta por varias décadas. Al respecto, y con todos los datos de la elección estadounidense para renovar el Congreso en noviembre de 2004, el doctor Luis Rubio señala que:

En la pasada elección de noviembre, por ejemplo, la mayoría de los Diputados y prácticamente todos los Sanadores que compitieron fueron reelectos. De los 435 curules en la Cámara Baja, en 356 el Diputado contaba con una ventaja superior al $20 \%$ respecto a sus contrincantes aún antes de comenzar la campaña. Y sólo 14 de los 100 Senadores enfrentaron contiendas competitivas. Todo esto lleva a la conclusión evidente de que el sistema electoral estadounidense no está diseñado para generar una gran alternancia de legisladores. Pero de ahí no se puede concluir que los legisladores guarden distancia de sus votantes, al contrario. ${ }^{39}$

Sobre el mismo tópico Jorge Buendía Laredo también comparte el punto de vista del doctor Rubio al establecer que:

Es un hecho ya probado, al menos en el caso de los Estados Unidos, que los legisladores tienen una serie de ventajas sobre sus competidores, como es el hecho de ser más conocidos, tener más recursos a su disposición y generar una clientela electoral estable. Se estima que aproximadamente el 10 u $11 \%$ de los votos de los legisladores provienen exclusivamente de las ventajas de detentar la diputación. En situaciones de alta competitividad, como la que vivimos ahora en México, estas ventajas pueden ser cruciales para definir al ganador de una elección distrital. ${ }^{40}$

Como nos podemos percatar, la experiencia estadounidense ha generado evidencia empírica de que la reelección misma genera una serie de ventajas para los legisladores, en detrimento de sus competidores. Una ventaja vital de la que gozan los legisladores es que son más conocidos entre sus votantes que sus competidores, son más conocidos porque han gastado más tiempo, dinero y energía en tal propósito, al respecto algunos analistas señalan que lo mismo puede argumentarse por ejemplo, con los cargos a gobernador en aquéllos países que permiten la reelección inmediata de estos

39 Rubio, Luis, México: democracia ineficaz, México, Cámara de Diputados, 2006, p. 146.

40 Buendía Laredo, Jorge, “Reelección ¿para qué?”, México, Nexos, octubre de 1998, p. 12. 
funcionarios públicos y que por lo tanto esta desventaja no sólo se aplica para los candidatos a un cargo legislativo, sino en general, para todos los candidatos en todos los niveles de gobierno en aquéllos países que permiten la reelección y lo anterior no significa que estos servidores públicos se perpetúen en el poder eternamente ya que hay altos índices de alternancia y por lo tanto este argumento pierde fuerza, sin embargo, en mi opinión en el caso de los candidatos a gobernadores $u$ otros funcionarios de mayor nivel, esto no es así porque en esos casos, tanto el político que está en el cargo, como el candidato nuevo son protagonistas muy reconocidos entre la sociedad lo que no ocurre en el caso de los legisladores y sus competidores ya que en este caso, salvo algunas excepciones, los competidores son unos auténticos desconocidos para los electores. Por lo anterior es que debemos de tener muy en cuenta este potencial peligro a la hora de restablecer la reelección e introducir ciertos candados y mecanismos en la reforma que propicien que este sin duda gran privilegio de que gozan los legisladores sea lo menos ventajoso posible. Ahora bien, si bien reconozco como ya ha quedado expuesto que un legislador tiene ventajas significativas en relación con sus competidores, también hay que tomar en cuenta que esta situación propiciaría una competencia más reñida por ganar el voto del electorado, lo cual a su vez tendría efectos positivos puesto que si un candidato quiere obtener el cargo que ostenta el legislador sabe que tendrá que presentar una candidatura mucho más atractiva que la del legislador, así como una mejor plataforma electoral, lo cual en teoría redundaría en una competencia de mucho mayor calidad. No hay que olvidar además que la reelección no sería automática para el legislador sino que tiene que convencer a su base electoral con argumentos sólidos y principalmente con resultados concretos que su labor ha sido por lo menos aceptable y en caso de no ser así éste por más proselitismo que realice, por más recursos que despliegue, no logrará la reelección y se puede considerar entonces que en este caso, el candidato opositor incrementaría sus posibilidades de ganar ya que no hay que olvidar que el camino más corto al poder es precisamente ese, la oposición.

A pesar de las anteriores consideraciones, insisto, el riesgo de que los legisladores acumulen recursos que representen una ventaja importante con respecto a sus rivales es una verdad que no podemos ignorar y mucho menos omitir, sin embargo, contra este efecto negativo de la reelección inmediata existe la opción, de optar por imponer restricciones a la reelección, tales 
como: un límite al número de las mismas, diferentes topes de campaña para el legislador y para sus rivales etcétera.

Para finalizar podemos señalar entonces, que a pesar de que la mayoría de los argumentos en contra de la reelección están bien fundamentados, éstos pueden refutarse con otros mecanismos para ofrecer una reforma mucho más completa y previsora, a modo de poder sortear las dificultades. Como podemos apreciar, estos argumentos no son contundentes, ya que a excepción del argumento relativo a la inequidad los restantes son más bien superficiales, como es el caso de la pérdida de la disciplina partidista ya que las dirigencias nacionales, como quedó asentado, a pesar de la reelección todavía tendrían muchos mecanismos para imponer la disciplina, por lo que no debemos temer a la reforma y buscar más pretextos para seguir manteniendo el esquema actual, como ya había explicado en páginas anteriores toda reforma política en cualquier parte del mundo tiene un costo ya que no hay reformas perfectas, sin embargo todas son perfectibles.

\section{CONCLUSIONES.}

Primera. Desde la Constitución Federal de 1824 y hasta 1933, ininterrumpidamente en ese periodo se permitió la reelección inmediata de los miembros del Poder Legislativo, es decir, la Constitución de 1917 en su texto original no prohibió la reelección de los miembros del Poder Legislativo, pues no la considero peligrosa dados los antecedentes.

Segunda. La prohibición de la reelección legislativa inmediata se estableció hasta 1933, producto del acuerdo de una asamblea extraordinaria del partido político mayoritario y dominante. Sin que ésta haya sido producto de un debate amplio, ilustrado y sereno en el que participaran todas las fuerzas políticas y sin que el clamor popular se manifestara al respecto.

Tercera. El desorden parlamentario imperante en el periodo de Plutarco Elías Calles y sobre todo después de la muerte del presidente, el general Álvaro Obregón, puso a la orden del día la necesidad de crear un partido político nacional que unificara y disciplinara a la gran diversidad de los sectores sociales, por lo cual se requería estabilidad y centralización del poder, teniendo como medio de control político discrecional la selección de candidatos a las legislaturas cada tres y seis años.

Cuarta. Como consecuencia de la prohibición constitucional de reelección legislativa inmediata, por más de 70 años hemos tenido sistemáticamente un 
Poder Legislativo amateur, débil, poco institucionalizado y sin especialización, ya que incluso aquellos que han participado en dos o tres legislaturas distintas, no puede decirse que son profesionales de las materias sobre las que legislan por no tener continuidad en el trabajo.

Quinta. El principio de la no reelección legislativa inmediata se ha mantenido incólume durante décadas debido a la eficacia con que le garantizó durante lustros una mayoría estable y subordinada al presidente de la República en la época del presidencialismo hegemónico y autoritario, lo cual junto con la no reelección presidencial también se tradujo en la estabilidad del sistema y en la garantía de gobernabilidad del mismo.

Sexta. En nuestro país la reelección está totalmente prohibida para el Poder Ejecutivo, no así para los miembros del Poder Legislativo en cuyo caso encontramos una prohibición relativa de la reelección, ya que constitucionalmente no podrán volver a ocupar el mismo cargo, sino pasando al menos una legislatura.

Séptima. Las condiciones que hicieron posible el establecimiento y permanencia del principio de la reelección legislativa inmediata, hoy en día han desaparecido por lo que el restablecimiento de la reelección legislativa inmediata debe ser parte importante de la reforma del Estado mexicano.

Octava. De las distintas democracias más significativas del orbe, se desprende que sólo México y Costa Rica prohíben la reelección legislativa inmediata. Ahora nuestro país avanza democráticamente y en ese sentido para el fortalecimiento y equilibrio de los poderes del Estado, se requiere entre otros aspectos, necesariamente la reelección inmediata de los legisladores.

Novena. De restablecerse la reelección legislativa inmediata ésta reportaría importantes beneficios para el legislador y para el Poder Legislativo mexicano en su conjunto tales como la profesionalización y especialización efectiva del legislador, la rendición real de cuentas y el fortalecimiento de la democracia, así como el fortalecimiento de las relaciones interpartidarias.

Décima. El restablecimiento de la reelección también podría traer consecuencias negativas si ésta no se implementa bien, tales como el enquistamiento y poca circulación de cuadros, conflicto de intereses distritales y partidistas y eventual pérdida de la disciplina parlamentaria así como la inequidad en la competencia por el cargo, sin embargo ha quedado demostrado que sólo este último constituye un peligro real, puesto que los restantes sólo están basados en suposiciones y falsas percepciones. 
Decimoprimera. Para que sea una correcta y efectiva reimplantación de esta propuesta, se requieren del establecimiento de otras reformas, así como limitar el número de periodos por lo que un legislador pueda reelegirse.

Decimosegunda. Por eso considero que el tiempo máximo que debe permanecer un legislador consecutivamente en su curul sean doce años y esto sólo se permita a los legisladores que postulen por el principio de mayoría.

\section{BIBLIOGRAFÍA}

ANDREA SÁNCHEZ, Francisco José de, "Reelección legislativa consecutiva: una iniciativa de reforma riesgosa", Boletín Mexicano de Derecho Comparado, núm. 103, México, enero-abril de 2002.

ARNAUT, Alberto, "La no reelección consecutiva de legisladores" México, Crónica Legislativa, 2001; Fernández Ruiz, Jorge, Poder Legislativo, México, Porrúa, 2003.

CABANEllas DE TORRES, Guillermo, Diccionario jurídico elemental, Argentina, Heliastra, 1988.

CANTÚ, María Elena. "Es el momento para la reelección", México, Refor$m a$, año 11, núm. 3310, 8 de enero de 2004. AIV

CAREY, John, "Discipline, Accountability and Legislative Voting in Latin America", en Albany, Comparative Politics, vol. 35, núm. 2, enero de2003.

CARPIZO MACGREgOR, Jorge, Nuevos estudios constitucionales, México, Porrúa, 2000. , Estudios jurídicos en torno a la Constitución de 1917, México, UNAM, 1998.

CASAR, María Amparo, "Las relaciones entre el Poder Ejecutivo y el Legislativo: el caso de México", Política y Gobierno, México, vol. VI, núm.1, enero-junio de 1999.

COLOMER, Joseph, Reflexiones sobre la reforma politica en México, México, Centro de Investigación y Docencia Económicas, 2003.

DAHL, Robert, La poliarquia: participación y oposición, 2a. ed., Madrid, Tecnos, 1997.

DAHRENDORF, Ralf, La democracia en Europa, trad. de Diana Zegarra, Madrid, Alianza, 1993.

Downs, Anthony, Teoría económica de la democracia, Madrid, Aguilar, 1973. 
DWORAK, Fernando (coord.), El legislador a examen, el debate sobre la reelección en México, México, Fondo de Cultura Económica-Cámara de Diputados. 2002.

GONZÁLEZ OropeZA, Manuel, "¿Qué hacer con el Congreso de la Unión?", Memoria del Tercer Congreso de Derecho Constitucional, México, UNAM, 1987, t. II.

HERNÁNDEZ RODRÍGUEZ, Rogelio, La reelección en el Poder Legislativo en México, México, El Colegio de México, 1991.

HERRERA, Jorge y TEHERÁN, Jorge, "Rechazan partidos la reelección presidencial", El Universal, México, año LXXXVIII, t. CCCXLIX, núm. 31,532, 20 de febrero de 2004.

HERRERA, Jorge, "IFE: utópico, pensar en la extinción del fraude" México, El Universal, año LXXXVII, t. CCCXLV, núm. 31, 10018 de febrero de 2003. HIDALGO, Arturo, "Académicos a favor de la reelección legislativa sucesiva", Reforma, México, año 10, núm. 3115, 7 de mayo de 2005.

LuJAMBIO, Alonso, "La reelección de los legisladores: las ventajas y los dilemas", México, Quórum, enero de 1996.

MANIN, Bernard, Los principios del gobierno representativo, 3a. ed., trad. de Fernando Vallespín, Madrid, Alianza, 2006.

MaquiaVelo, Nicolás, El príncipe, 23a. ed., México, Porrúa, 2005.

MaYHew, David, Congress. The Electoral Connection, New Haven, Yale University Press, 1979.

Moreno Collado, Jorge, El debate en torno a la reelección de los diputados y senadores, México, Porrúa-LVI Legislatura, Cámara de Diputados, 1996.

NACIF, Benito, "Para comprender la disciplina de modelo de partido en la Cámara de Diputados de México: el modelo de partido centralizado", México, Foro Internacional, núm. 1, enero-marzo de 2002.

NoHLEN, Dieter et al., Tratado de derecho electoral comparado en América Latina, México, Fondo de Cultura Económica-Instituto Interamericano de Derechos Humanos, 1998.

Rubio, Luis, México: democracia ineficaz, México, Cámara de Diputados, 2006.

SANTO, Víctor de, Diccionario de ciencias jurídicas, políticas, sociales y de economía, 2a. ed., Argentina, Universidad, 1999.

SARTORI, Giovanni, Ingeniería constitucional comparada, 4a. ed., México, Fondo de Cultura Económica, 1999. 
SCHMitTER, Phillipe, Transiciones desde un gobierno autoritario, vol. 2, América Latina, Barcelona, Paidós, 1994.

Silva-Herzog MÁrquez, Jesús, El antiguo régimen y la transición en México, México, Planeta, 2003.

TEHERÁN, Jorge, "El ex procurador Carpizo advierte sobre las reformas a la Constitución", El Universal, México, año LXXXVII, t. CCCLXV, núm. 31, 108, 26 de febrero de 2005.

Tena RAmírez, Felipe, Derecho constitucional mexicano, 37a. ed., México, Porrúa, 2005.

Ugalde, Luis Carlos, "La reelección en México", Nexos, núm. 47, mayo de 1992.

Weldon, Jeffrey, No-Reelection and the Mexican Congress, propuesta de disertación doctoral, San Diego, Universidad de California, 1991. 